Mini Review

\title{
HEALTH PROMOTING CHEMICAL COMPONENTS OF ORANGE JUICE
}

\author{
Gaḷina Zvaigzne and Daina Kārklina \\ Latvia University of Agriculture, Lielā iela 2, Jelgava, LV-3001, LATVIA; \\ g.zvaigzne@inbox.lv, daina.karklina@llu.lv
}

Contributed by Daina Kārkliṇa

\begin{abstract}
Citrus fruit or juice can be an excellent source of health-promoting substances at breakfast. $A$ 150-200 ml glass of orange juice daily provides many nutrients required for good human health. As has been reported, vitamin $C$, thiamine (vitamin $B_{1}$ ), riboflavin, vitamin $A$, vitamin $D$, vitamin $E$, pantothenic acid, vitamin $B 6$, folate are present in oranges. Citrus juices also provide minerals calcium, potassium, iron, zinc, magnesium, copper, and phosphorous, which are part of the vital enzyme system of the human body. In addition, several compounds - flavonoids and other health-promoting substances are present in citrus fruit. There are hundreds of useful products and substances with properties, which have origin in citrus products. There are also many patents for helpful products to be made from citrus substances. Treatment of major inflammation-related ailments target on phytochemicals involved in oxidative stress, metabolic syndrome (diabetes), cardiovascular diseases, bone health (osteoporosis), skin aging, cognitive function and brain diseases, aging, allergy and immune function and cancer. A clinical study published shows that orange juice and hesperidin increase nitric oxide production in human. Orange juices have been shown to provide several important health benefits, particularly for the cardiovascular system, bone and skin health, brain health, cognitive functions, aging, and also cancer. However, the number of clinical studies available remains limited and significant efforts are necessary to provide irrefutable proof of these benefits in human.
\end{abstract}

Key words: naringin, hesperidin, orange juice, nitric oxide, vitamins.

\section{INTRODUCTION}

Citrus is the world's most popular fruit. Citrus products have always been valued as excellent sources of human nutrition. Nutrition is the ability to engender growth, and many of the components of citrus products contribute to the growth and well-being of the human body. It is well established that citrus and citrus products are a rich source of vitamins, minerals, flavonoids and dietary fibre NSP (nonstarch polysaccharides) and that are essential for normal growth and development and overall nutritional well-being. For example, the recommended dietary allowances for average adults in the United States and India in terms of nutrients available in citrus juices are given in Table 1.

In addition, citrus contains no fat or sodium and, being a plant food, no cholesterol. The average energy value of fresh citrus is also low (see Table 2), which can be very important for consumers concerned about putting on excess body weight. For example a medium orange contains 60 to $80 \mathrm{kcal}$, a grapefruit $90 \mathrm{kcal}$ and a tablespoon $(15 \mathrm{ml})$ of lemon juice only 4 kcal (Whitney and Rolfes, 1999).

\section{CARBOHYDRATES}

Citrus fruits contain carbohydrates in the form of sugars: sucrose, glucose, and fructose as well as citric acid, which can also provide a small amount of energy. Total soluble solids in juice consist mainly of sugars. Fibrous rag and many other polysaccharides, which may also provide calories, are also eaten when fresh citrus fruit is consumed (Ladaniya, 2008). A reasonable goal for dietary NSP/fibre intake is 25 to $30 \mathrm{~g} /$ day, but in many developed countries the actual average intake is closer to $15 \mathrm{~g}$ (Cleveland et al., 1996). With one medium orange containing approximately $3.0 \mathrm{~g}$ of NSP, citrus fruit can make a valuable contribution to meeting the daily fibre goal (Whitney and Rolfes, 1999). An averagesize orange (7-8 cm diameter) can provide $0.8 \mathrm{~g}$ of fibre in the diet. Drinking of a cup of fresh orange juice provides $0.3 \mathrm{~g}$ of fibre. A half grapefruit eaten at breakfast adds $0.2 \mathrm{~g}$ of fibre to the meal, thus replacing fibre that has been removed from the breakfast cereal by the milling process (Church and Church, 1970). Fibre has its own importance for the people of industrialized nations who eat high-fat, low-fibre diets full of highly refined and processed carbohy- 
RECOMMENDED DIETARY ALLOWANCES FOR AVERAGE ADULTS IN THE UNITED STATES AND INDIA IN TERMS OF NUTRIENTS AVAILABLE IN CITRUS JUICES (one glass, $100 \mathrm{~g}$ )

\begin{tabular}{|c|c|c|c|c|c|}
\hline \multirow[b]{2}{*}{ Nutrient } & \multicolumn{2}{|c|}{ Recommended dietary allowance } & \multicolumn{3}{|c|}{ Content in citrus juices } \\
\hline & $\begin{array}{l}\text { essential in human } \\
\text { nutrition (USRDA) }\end{array}$ & $\begin{array}{c}\text { for average adult Indian } \\
(60 \mathrm{~kg} \text { weight })\end{array}$ & orange & tangerine & grapefruit \\
\hline Vitamin $\mathrm{C}$ & $90 \mathrm{mg}$ & $40 \mathrm{mg}$ & $45-50 \mathrm{mg}$ & $30-31 \mathrm{mg}$ & $30-35 \mathrm{mg}$ \\
\hline Vitamin A & $5000 \mathrm{IU}$ & $600 \mu \mathrm{g}$ retinal & 190-400 IU & $350-420 \mathrm{IU}$ & $21 \mathrm{IU}$ \\
\hline Vitamin D & $200 \mathrm{IU}$ & - & - & - & - \\
\hline Vitamin E & $15 \mathrm{mg}$ & $25 \mu \mathrm{g}$ & $100 \mu \mathrm{g}$ & - & - \\
\hline Riboflavin & $1.7 \mathrm{mg}$ & $1.6 \mathrm{mg}$ & $20-40 \mu \mathrm{g}$ & $20-40 \mu \mathrm{g}$ & - \\
\hline Niacin & $20 \mathrm{mg}$ & - & $300-600 \mu \mathrm{g}$ & $200-250 \mu \mathrm{g}$ & $200 \mu \mathrm{g}$ \\
\hline Calcium & $1 \mathrm{~g}$ & $400-1000 \mathrm{mg}$ & $10-11 \mathrm{mg}$ & - & $9-10 \mathrm{mg}$ \\
\hline Iron & $18 \mathrm{mg}$ & $28 \mathrm{mg}$ & $0.1-0.2 \mathrm{mg}$ & - & - \\
\hline Pyridoxine $\left(\mathrm{B}_{6}\right)$ & $2 \mathrm{mg}$ & $2.0 \mathrm{mg}$ & $47-66 \mu \mathrm{g}$ & $40-50 \mu \mathrm{g}$ & $18-20 \mu \mathrm{g}$ \\
\hline Folic acid & $0.4 \mathrm{mg}$ & $100 \mu \mathrm{g}$ & $34 \mu \mathrm{g}$ & $21 \mu \mathrm{g}$ & $8 \mu \mathrm{g}$ \\
\hline Vitamin $\mathrm{B}_{12}$ & $5-6 \mu \mathrm{g}$ & $1 \mu \mathrm{g}$ & - & - & - \\
\hline Iodine & $150 \mu \mathrm{g}$ & - & $0.25 \mu \mathrm{g}$ & - & - \\
\hline Magnesium & $400 \mathrm{mg}$ & - & $8-12 \mathrm{mg}$ & $10-15 \mathrm{mg}$ & $8-10 \mathrm{mg}$ \\
\hline Zinc & $15 \mathrm{mg}$ & - & $25-30 \mu \mathrm{g}$ & - & - \\
\hline Copper & $2 \mathrm{mg}$ & - & $50-160 \mu \mathrm{g}$ & - & - \\
\hline Biotin & $0.3 \mathrm{mg}$ & - & - & - & - \\
\hline Pantothenic acid & $10 \mathrm{mg}$ & - & $130-150 \mu \mathrm{g}$ & - & $280-300 \mu \mathrm{g}$ \\
\hline
\end{tabular}

Source: Anonymous (2004a); Gopalan et al. (1999). USRDA, United States Recommended Daily Allowance

Table 2

NUTRITIONAL FACTS ON CITRUS FRUIT

\begin{tabular}{l|c|c|c}
\hline \multicolumn{1}{c|}{$\begin{array}{c}\text { Weight } \\
(\mathrm{g})\end{array}$} & $\begin{array}{c}\text { Orange } \\
131\end{array}$ & $\begin{array}{c}\text { Grapefruit } \\
236\end{array}$ & $\begin{array}{c}\text { Tangerine } \\
84\end{array}$ \\
\hline Energy $(\mathrm{kcal})$ & 62 & 78 & 37 \\
Fibre $(\mathrm{g})$ & 3.1 & 2.5 & 1.7 \\
Ascorbic acid $(\mathrm{mg})$ & 70 & 79 & 26 \\
Folate $(\mu \mathrm{g})$ & 40 & 24 & 17 \\
Potassium $(\mathrm{mg})$ & 237 & 350 & 132
\end{tabular}

Source: Gutherie and Picciano, 1995.

drates that are more slowly absorbed through the intestines. In fresh citrus fruit, fibre contains cellulose, hemicellulose, lignin, and pectin - all found in citrus segments, membranes and other parts of the albedo (Ladaniya, 2008). Dietary fibre also adsorbs calcium and may increase its availability (Nishimura et al., 1992). Citrus fruits are not considered a major source of protein; but proteins are a constituent of citrus juices. In citrus fruits, seeds are very rich in protein. Citrus seeds contain $18.2 \%$ protein on a dry weight basis (in whole seeds) (Ladaniya, 2008).

\section{MINERALS}

Citrus juices also provide minerals that are part of the vital enzyme system of the human body. Citrus fruits have very high potassium $(\mathrm{K})$ content $(300 \mathrm{mg}$ in $178 \mathrm{ml}$ of orange juice and $200 \mathrm{mg}$ in grapefruit juice), while the sodium content is relatively low (3-4 mg/178 $\mathrm{ml}$ orange juice and $4.5 \mathrm{mg} / 178 \mathrm{ml}$ tangerine juice). The ratio of $\mathrm{K}$ and sodium
(Na) in orange juice plays an important role in maintaining electrolyte balance. Dietary levels are 50-150 meq (milliequivalent) per day for potassium (Araujo, 1977). The daily requirement of potassium is approximately $2000 \mathrm{mg}$ and, while frank deficiency of potassium is rare, there is some concern that a high sodium-to-potassium intake ratio may be a risk factor for chronic disease. Increased consumption of citrus fruits and juices is a good means of increasing potassium intake. One medium orange and one $225 \mathrm{ml}$ glass of orange juice provide approximately $235 \mathrm{mg}$ and $500 \mathrm{mg}$ of potassium, respectively (Whitney and Rolfes, 1999). The RDA for calcium in the diet of adult Indian men is $400 \mathrm{mg}$ per day; one orange provides about $2 \%$ of this amount. In addition to $\mathrm{K}$ and $\mathrm{Na}$, calcium and phosphorus, and magnesium are required in higher amounts. Like calcium and phosphorus, magnesium is sequestered in bone. Magnesium is present in mitochondria and other enzymes important in energy transfer. Zinc, manganese, and copper are also important for the body and supplied by citrus fruits. Ascorbic acid and citric acid increase the absorption of calcium and other minerals. A study indicated that ascorbic acid was not the only organic acid responsible for promoting the effects of citrus fruit juices on iron absorption. Iron absorption from laboratory orange juice containing $100 \mathrm{ml}$ water, 33 $\mathrm{mg}$ ascorbic acid, and $750 \mathrm{mg}$ citric acid was significantly better than that from $100 \mathrm{ml}$ water and $33 \mathrm{mg}$ ascorbic acid alone (0.097 and $0.059 \mathrm{~g}$, respectively). There was a close correlation between iron absorption and ascorbic acid content. A weaker but still significant correlation with the citric acid content also was observed (Ballot et al., 1987). A glass of chilled orange juice or few fresh oranges or mandarins are very refreshing in summer and also provide required 
electrolytes. One orange (200 g) provides about $2 \mathrm{mg}$ of iron. Two oranges a days can give $4 \mathrm{mg}$, which would be more than $10 \%$ of the Recommended Dietary Allowance (RDA) in the USA. The RDA is set assuming a $10 \%$ rate of intestinal absorption (Ladaniya, 2008).

\section{VITAMINS}

Ascorbic acid (vitamin C) is the most important nutrient in orange juice. Vitamin $\mathrm{C}$ is essential for the synthesis of collagen, the most abundant protein in mammals. Collagen is the major fibrous element of skin, bone, blood vessels and teeth. A lack of vitamin $\mathrm{C}$ leads to scurvy, which causes loss of teeth, bleeding skin and ulcers. Vitamin C is sometimes suggested to have anticancer effect by its reaction with and inactivation of tree radicals in the body. It is estimated that a glass of orange juice $(177.4 \mathrm{ml}$; Ladaniya, 2008) provides about $100 \%$ of the recommended daily allowance of vitamin $\mathrm{C}$ to the average American diet. The RDA set in 2000 for an average adult of good health is 75-90 $\mathrm{mg}$ (Anonymous, 2004). Too much vitamin C (above $500 \mathrm{mg}$ ), generally seen with very high levels of supplementation, may be dangerous, especially for those at risk of iron overload (Fleming et al., 1998). Consuming five servings of fruits and vegetables each day can result in an intake of about $200 \mathrm{mg}$ of vitamin C. Citrus fruits are a particularly good source of vitamin $\mathrm{C}$, with one medium orange or grapefruit providing approximately $70 \mathrm{mg}$ and 56 $\mathrm{mg}$, respectively. A $225 \mathrm{ml}$ glass of orange juice contains approximately $125 \mathrm{mg}$ of vitamin C (Whitney and Rolfes, 1999).

Among other vitamins present in fresh citrus fruit are compounds of the vitamin B complex. Folic acid, which is heat-sensitive and lost in food processing, can be obtained from fresh oranges, mandarins, and grapefruits. Folic acid or folate is required for the multiplication and maturation of red blood corpuscles; its deficiency can result in a type of anaemia. Folic acid plays a role in metabolic pathways by the formation of purine and pyrimidine nucleotides as well as certain amino acid conversions. Since growth requires proteins and nucleic acid synthesis, growing children and pregnant women are more sensitive to its deficiency (Ladaniya, 2008). Folate has also been associated with a reduced risk of heart disease by lowering blood serum homocysteine levels. Women at child-bearing age and those at the greatest risk of coronary heart diseases need to take sufficient folate in their diet (Widmer and Stinson, 2000). In the United States, recommended daily intake of folate is $180 \mathrm{mcg}$ for females and $200 \mathrm{mcg}$ for males. Over the past decade, however, it has become clear that higher levels of folic, $400 \mathrm{mcg}$, are associated with the prevention of neural tube defects, a severe birth defect (Center for Disease Control and Prevention, 1992). Thiamin (Vitamin $\mathrm{B}_{1}$ ) content ranges from 90 to $280 \mathrm{mcg}$ in a serving of $177 \mathrm{ml}$ of oranges, juice, which is 6-18\% of the USRDA (United States Recommended Daily Allowance)*.

\footnotetext{
* http://1stholistic.com/nutrition/hol_nutrition-RDA.htm
}

Citrus fruits are also a source of the $\mathrm{B}_{6}$ vitamins, known as pyridoxal, pyridoxamine and pyridoxine. These are interchangeable in the body. Some types of stomatitis and a type of anemia have been shown to be cured by the administration of pyridoxine. The average intake of $0.6-2.5 \mathrm{mg}$ of $\mathrm{B}_{6}$ is considered sufficient for all age groups of Indians (Gopalan et al., 1999).

\section{PHYTOCHEMICALS}

The effects of flavonoids from citrus juices, particularly those found in oranges and grapefruit, on blood circulation, as well as their anti-allergenic, anti-carcinogenic, and antiviral properties have been discussed by Rice-Evans et al. (1997), Filatova and Kolesnova (1999), who reviewed the antioxidant properties of phenolic compounds.

The effects of the citrus bioflavonoid naringin were tested by using it as a supplement in a high-cholesterol diet (Shin et al., 1999). A research team, from the University of East Anglia, UK, reported that women consuming the highest amounts of flavanones, a subclass of flavonoids that are found in especially high levels in citrus fruits, were associated with up to a $19 \%$ reduction in stroke risk, compared to those in the group who consumed the lowest amount (Cassidy et al., 2012).

\section{ROLE OF CITRUS FRUIT IN REDUCING RISK OF HU- MAN DISEASES}

Dietary fibre is reported to lower the incidence of ischemic heart diseases (Trowell, 1972). Synthetic fibrous substances have been utilised to promote the lowering of blood cholesterol from the intestinal lumen. Garvin et al. (1965) and Resnicow et al. (1991) reported that a type of strict vegetarian diet that is typically very low in saturated fat and dietary cholesterol and high in fibre can help children and adults maintain or achieve a desirable blood lipid level. Each $1 \%$ reduction in blood cholesterol yields an approximately $2 \%$ reduction in risk of coronary heart disease; thus a $7.6 \%$ decrease translates to a $15 \%$ decrease in the risk of coronary heart disease. Thus, without drastically changing lifestyle and/or diet, cholesterol levels can be lowered, and it also has been established that atherosclerosis is retarded in pigs fed a grapefruit pectin atherogenic diet (Attaway and Moore, 1992). These findings are important for people who have established atherosclerosis and whose only remedy at present is bypass surgery. These studies all indicated beneficial aspects of eating oranges and tangerines, showing that certain compounds, mostly flavonones, are promising for lowering low density lipoprotein cholesterol (so-called "bad cholesterol"), without causing any harmful side effects. Studies conducted by USDA with KGK Synergise Inc, Canada, have also shown that antioxidant compounds (called polymethoxylatedflavors, or PMF) are the most potent in reducing cholesterol (Anonymous, 2004b). Diets rich in citrus and citrus- based products have been negatively correlated with the risk of cardiovascular disease. Studies have 
been conducted to determine whether naringenin and hesperetin, two major flavanones in citrus plants, influence endothelium nitric oxide production (Liu et al., 2008). Limonoids (a group of triterpenoids) in citrus fruits possess important biological activity. The similar chemical structure of citrus limonoids to those of recognised anti-tumour agents led to their evaluation as potential anti-tumour agents in mammalian systems. Studies in mice showed that citrus limonoids induced a significant amount of the chemical carcinogen detoxifying enzyme system glutathione-s-transferase in the liver and intestinal mucosa. In-vitro tests with human breast cancer cells have shown that limonoids have significant anti-tumour activity (Manners and Hasegawa, 2000). Consumption of peel products is associated with reduced risk of squamous-cell carcinoma of the skin, as reported by I. A. Hakin and R. B. Harris of the Arizona Cancer Center (Anonymous, 2004c). Modified citrus pectin was also observed to interfere with the metastasis of other cancer cells. The alcohol of citrus peel is active in inducing apoptosis in tumour cells without affecting normal cells and can revert tumour cells back to a differentiated state. Applying peel extracts can inhibit the growth of melanoma and other skin cancer cells (Anonymous, 2004c).

Orange juice has also been reported to prevent the formation of kidney stones, due to the presence of citrates (Anonymous, 2006). Kidney stones are formed when urine is too concentrated, causing minerals and other chemicals in the urine to bind together. The studies of Dr. Clarita Odvima, UT, South-Western Medical Centre, indicated that orange juice increased the level of citrates in urine and reduced crystallisation of uric acid and calcium oxalate (Anonymous, 2006). The study indicated that potassium citrate, a generally prescribed medicine, had gastrointestinal side effects in some patients and therefore orange juice was the better option.

\section{CONCLUSIONS}

Orange juices have been shown to provide several important health benefits, particularly for the cardiovascular system, bone and skin health, brain health and cognitive functions, aging and also cancer. However the number of clinical studies available remains limited and significant efforts are necessary to provide irrefutable proof of these benefits in human.

\section{REFERENCES}

Anonymous (2004a). Food and Nutrition Board. Recommended Dietary Allowances. $9^{\text {th }}$ revised edition. Washington: National Academy of Sciences. http://www.iom.edu/Global/News\%20Announcements/ /media/Files/Activity\%20Files/Nutrition/DRIs/DRI_Summary_Listing.pdf

Anonymous (2004b). Healthy citrus. Citrus Industry Florida, 85 (8), 40.

Anonymous (2004c). Citrus buzz. Citrus Industry Florida, 85 (3), 5-6.
Anonymous (2006). Orange juice prevents recurrence of kidney stones. The Hitavada, September 2.

Araujo, P. E. (1977). Role of citrus fruit in Human Nutrition. In: Nagy, S., Shaw, P.E., Veldhuis, M.K. (eds.). Citrus Science and Technology (pp. 1-32). WestPort, CT: AVI Publishing Co.

Attaway, J. A., Moore, E. I. (1992). Newly discovered health benefits of citrus fruits and juices. In: Proceedings of the $7^{\text {th }}$ International Citrus. Congress, Acireale, Italy. Vol. 3 (pp. 1136-1139). Acireale (Italy): International Society of Citriculture.

Ballot, D., Baynes, R. D., Bothwell, T. H., Gillooly, M., Macfarlane, B. L., Macphail, A. P., Lyons, G., Derman, D. P., Bezwoda, W. R., Torrance, J. D., Bothwell, J. E., Mayet, F. (1987). The effects of fruit juices and fruits on the absorption of iron from rise meal. J. Brit. Nutr., 57, 555-559.

Cassidy A., Rimm, E.B., O'Reilly, É.J., Logroscino, G. (2012). Dietary flavonoids and risk of stroke in women. Stroke, 43 (4), 946-951.

Church, C. J., Church, W. A. (1970). Food Values of Commonly Used Portions of Fruits and Vegetables. Philadelphia, PA: Lippincott Publishing Company,

Cleveland, L. E., Goldman, J. D., Borr, L. G. (1996). Continuing Survey of Food Intakes by individuals diet and Health Knowledge Survey. Retrieved August, 27, 2012, from

http://www.ars.usda.gov/SP2UserFiles/Place/12355000/pdf/Tbs1994.PDF

Fleming, D., Jacques, P., Dallal, G., Tucker, K., Wilson, P., Wood, R. (1998). Dietary determinants of iron stores in a free living elderly population: The Framingham Heart Study. Amer. J. Clin. Nutr., 67, 722-733.

Garvin, J. E., Forman, D. T., Eiseman, W. R., Phillips, C. R., (1965). Lowering of human serum cholesterol by an oral hydrophilic colloid. Abstract. Proc. Soc. Exp. Biol. Med., 120 (3), 744-746.

Gopalan, C., Sastri, V. P. R., Balasubramaniam, S. C. (1999). Nutritive Value of Indian Foods. Hyderabad: National Institute of Nutrition (Indian Council of Medical Research), 156. pp.

Gutherie, H., Picciano, M. (1995). Human Nutrition. St. Louis, MO: Mosby.

Ladaniya M. S. (eds.). (2008). Citrus Fruit Biology, Technology and Evaluation. Amsterdam: Elsevier. 558 pp.

Liu, L., Xu, D. M., Cheng, Y. Y. (2008). Distinct effects of naringenin and hesperetin on nitric oxide production from endothelial cells. J. Agr. Food Chem., 56 (3), 824-829.

Manners, G. D., Hasegava, S. (2000). Citrus limonoids: Potential chemoprevetative agents. In: Proceedings of the $9^{\text {th }}$ Citrus Congress, 3-7 December 2000, Orlando, Florida (p. 61). Orlando.

Nishimura, K., Yoshida, N., Kosaka, K. (1992). Absorption of calcium on dietary fibre from 'Konatsu', a local orange grown in Kochi Prefecture. $J$. Jap. Soc. Nutr. Ed. Sci., 45, 545-550.

Resnicow, K., Barone, J., Engle, A., Miller, S., Haley, N. J., Fleming, D., Wynder, E. (1991). Diet and serum lipids in vegan vegetarians: A model for risk reduction. J. Amer. Dietic Assoc., 91, 447-453.

Shin, Y. W., Bok, S. H., Jeong, T. S., Bae, K. H., Jeoung, N. H., Choi, M. S., Lee, S. H., Park, Y. B. (1999). Hypocholesterolemic effect of naringin associated with hepatic cholesterol regulating enzyme changes in rats. J. Vit.. Nutr. Res., 69 (5), 341-347.

Trowell, H. (1972). Ischemic heart disease and dietary fiber. Amer. J. Clin. Nutr. 25, 926-932.

Whitney, E., Rolfes, S. (1999). Understanding Nutrition. $8^{\text {th }}$ edn. Belmont, Ca: West/Wadsworth.

Widmer, W. W., Stinson, W. S. (2000). Health benefits of folate in orange juice. In: Proceedings of the $9^{\text {th }}$ Citrus Congress, 3-7 December 2000, Orlando, Florida (p. 62). Orlando.

Филатова И. А., Колеснов А. Ю. (1999). Значение флавоноидов цитрусовых соков в профилактике заболеваний [Significance of flavonoids from citrus juices in disease prevention]. Пищевая промыиленность, № 8, 62-63. 


\section{VESELĪBU VEICINOŠI K̦ĪMISKIE KOMPONENTI APELSĪNU SULĀ}

Citrusaug̣̣i un citrusaug̣̣u sulas ir lielisks veselības avots — veselību veicinošu vielu uzṇemšana brokastīs. 150-200 ml glāze apelsīnu sulas nodrošina daudzas veselībai labas uzturvielas, kuras nepieciešams uzņemt katru dienu. Apelsīni satur C vitamīnu, tiamīnu, riboflavīnus, A vitamīnu, D vitamīnu, E vitamīnu, pantotēnskābi, B6 vitamīnu, folijskābi. Citrusaug̣̣u sulas satur minerālvielas — kalciju, kāliju, dzelzi, cinku, magniju, varu, fosforu, kas ir daļa no svarīgās enzīmu sistēmas cilvēka organismā. Turklāt citrusaugḷu sula satur arī vairākus savienojumus - flavonoīdus un citus veselību veicinošas vielas. Ir simtiem noderīgu produktu un vielu ar šādām īpašībām, un to pirmavots ir citrusaug̣̣i. Ir daudz patentu par veselīgiem produktiem, kuru izgatavošanā izmantotas citrusaug̣̣u vielas. Svarīgu ar iekaisumiem saistītu slimību ārstēšanā izmanto fitoḳīmiskās vielas, saistībā ar tādām slimībām kā oksidatīvais stress, metabolais sindroms (diabēts), sirds un asinsvadu slimības, kaulu slimības (osteoporoze), ādas novecošana, kognitīvo funkciju un smadzeņu slimības, novecošana, alerğijas, imūnsistēmas funkcijas un vēzis. Klīniskajos pētījumos iegūtie un publicêtie dati liecina, ka apelsīnu sula un hesperidīns veicina slāpekḷa oksīda ražošanu cilvēkā. Ir pierādīts, ka apelsīnu sula nodrošina vairākus būtiskus veselības uzlabojumus, galvenokārt, saistībā ar sirds un asinsvadu slimībām, kaulu un ādas veselību, smadzenu darbību, kognitīvajām funkcijām, novecošanu un vēzi. Tomēr pieejamo klīnisko pētîjumu skaits ir ierobežots, ir nepieciešami jauni pētîjumi, lai sniegtu neapgāžamus pierādījumus šiem cilvēka veselības uzlabojumiem. 